\title{
An Empirical Analysis of the Link between Economic Growth and Exports in Côte d'Ivoire
}

\author{
Daouda Coulibaly ${ }^{1}$, \& Fulgence Zran Goueu ${ }^{1}$ \\ ${ }^{1}$ Peleforo Gon Coulibaly University, Department of Economics, Korhogo, Ivory Coast, Cote D'Ivoire \\ Correspondence: Daouda Coulibaly, Peleforo Gon Coulibaly University, Department of Economics, Korhogo, \\ Ivory Coast, Cote D'Ivoire.
}

Received: July 31, 2019

Accepted: August 16, $2019 \quad$ Online Published: August 29, 2019

doi:10.5539/ibr.v12n9p94

URL: https://doi.org/10.5539/ibr.v12n9p94

\begin{abstract}
This paper aims to analyze the relationship between exports and economic growth in Côte d'Ivoire. In order to achieve this objective, annual data for the period 1960-2017 were tested by using the cointegration approach of Pesaran, Shin and Smith, including the causality test of Breitung and Schreiber. According to our analysis it is only exports that drive economic growth and not the opposite. Exports act positively and significantly on economic growth in the short term as well as in the long term. The causality test of Breitung and schreiber indicates a one-way long-run causal relationship ranging from exports to gross domestic product (GDP). All those results show that exports are a source of Ivorian economic growth.
\end{abstract}

Keywords: Côte d'Ivoire, economic growth, exports, cointegration, causality, frequency band

\section{Introduction}

The analysis of the impacts of exports on economic growth, and vice versa, that of the effects of economic growth on exports has been debated by many studies in both theoretical and empirical economic literature. The debate that has been going on for more than thirty years concerns both developed and developing countries. One the main stakes of that debate is to allow the evaluation of the effects that an export-based strategy, and thus the openness policy can have on growth. Exports result from economic policy, which itself can influence the way exports affect economic growth (Balassa, 1985). Exports help a country to be more or less open to the outside world through many activities and a wide variety of economic policy decisions. Thus, any judgment based on economic measures likely to affect exports and therefore foreign trade (protection, exchange rate, taxation, direct control...) defines only the character of a country turned outward or inward; and this affects both the external and the internal balance of the country.

From the late 1970s to the late 1990s, many of the empirical studies conclude that there is a positive causal link between exports and economic growth. Since the late 1990s, these exports-based policies have been questioned by anti-globalization advocates because of their social impacts in developing countries. In fact, an increase in exports requires the creation of large markets and the diversification of products. It also calls for knowledge that is constantly renewed, including the possibility of exploiting increasing returns to scale and increasing human capital. Thus, exports are a real engine of economic growth, especially as productivity gains in exports sectors are spread to the entire national economy through the system of low relative prices of products. While for some authors, trade policy affects the evolution of exports, for others, the size of the country, the composition of its comparative advantages and its changes over time have a direct impact on exports growth.

Côte d'Ivoire is a free-market economy and open to the outside world. Before the independence, the growth and development of Ivorian economy was based on exports crops sector, particularly coffee and cocoa. This economic policy orientation growth was pursued by Ivorian planner after the independence. Thus, over the 1960-70 decade, economic growth depended mainly on the development of the primary product processing industry and the import-substitution industries. Between the years 1971-1980, changes were made to industrial policy by the transition from an import-substitution industry to the development of export industries. To accompany Ivorian companies to conquer foreign markets, in 1960, the World Bank, the private sector and the state of Côte d'Ivoire created the Association for the Promotion of Exports of Côte d'Ivoire (APEX-CI). In 2014, the Ivorian government created the National Exports Council (NEC), which is an adversary body working with the government and the private sector on issues related to the National Export Strategy (NES). Today, the 
authorities' goal is to make Côte d'Ivoire an emerging country by 2020, and exports are a central pillar in achieving this goal. From 34.24\% in 1960, the share of exports in GDP reached the value of $53.82 \%$ in 2011 before falling gradually to $34.01 \%$ in 2017 . Despite all these development policies implementation and with its laudable goals, the country ranks among lower-middle-income countries and its growth remain focused on exports of low value-added primary agricultural products.

This paper aims to determine the nature of the links between economic growth and exports of Côte d'Ivoire. Do exports cause economic growth? Or it is rather economic growth that causes exports. Or is it a circular causality? What is the influence impact in the short and long-run? To do this, we use the Breitung and Schreiber (2016) causality test and the cointegration test of Pesaran, Shin and Smith (2001) to analyze the nature of the relationship between exports and Ivorian economic growth.

The rest of the article is structured as follows. Section 2 presents a brief review of the literature. In Section 3 we put forward the methodology. The results of the estimates are discussed in Section4 and we end with the conclusion.

\section{Literature Review}

The degree, nature and sense of the relationship between exports and economic growth have been greatly examined in the economic literature. The results depend both on the nature of the data and the estimation methods used. In a cross-sectional analysis, Michaely (1977) uses spearman's correlation coefficient to study the link between exports and economic growth for a number of countries over the period 1950-1973. For a group of non-developed countries, he finds a correlation coefficient of the order of 0.38 and significant at $1 \%$; this coefficient is slightly higher $(0.523)$ for countries with income over $300 \$$. As for the less developed countries, he obtains a correlation coefficient that is practically zero. Heller and Porter (1978) confirm Michaely's results by testing the correlation between the growth rate of exports and the growth rate of non-exported component of production. Indeed they obtain a spearman's correlation coefficient of 0.57 for the richest countries and 0.09 for the others. With a sample of 55 developing countries, Tyler (1981) confirms, over the period 1960-1977, the positive role of exports on economic growth. Wei (1993) in his study of Chinese cities observes that the growth of these cities was driven by exports over the period 1980-1990 and by foreign investment during the period 1988-1990. As for Colombatto (1990), he rejects the export-led growth assumption in a sample of 70 less developed countries using the Ordinary Least Squares method.

Using quarterly data from 1976 to 2003, Al Mamun and Nath (2005) found a positive and significant long-run relationship between exports and industrial production in Bangladesh. Kpemoua (2016) also finds a positive and significant correlation at $1 \%$ level in long-run between exports and economic growth in Togo over the period 1960-2014. Similar results were obtained by Saminirina and Adamson (2013), Mohsen (2015), Fatemah and Qayyum (2018). Indeed, Saminirina and Adamson show that a 10\% increase in exports leads to an economic growth of 0.95\% in Madagascar. Mohsen notes that in Syria over the period 1975-2010, exports as a whole (oil exports and non-oil exports) have a positive and significant impact on long-run economic growth with a larger effect of non-oil exports. Fatemah and Qayyum conclude that exports are an important and significant determinant of economic growth in Pakistan using the cointegration test of Johansen $(1988,1991)$ and the estimation of an Error Correction Model. Ee (2016) uses a cointegrated panel data to test the validity of the export-led growth hypothesis in three African countries over the period 1985-2014. The estimation made according to the methods Fully Modified Ordinary Least Squares (FMOLS) and Dynamic Ordinary Least Squares (DOLS) reveals that exports act positively and significantly on economic growth. Kalaitzi and Cleeve (2018) show that the exports of manufactured goods and primary products have a positive and significant impact on long-run economic growth with a greater impact of manufacturing exports. However, in the case of five Asian countries, Vohra (2001) specifies that the positive and significant impact of exports on economic growth depends on the level of economic development achieved by the country. Subasat (2002) demonstrates that exports promotion has no significant impact on economic growth in low-income and high-income countries. He also shows that countries which are more open to exports and middle-income countries are growing faster than countries relatively less open to exports.

The existence of a correlation relationship between the gross domestic product and exports does not give any precision as to the meaning of the causality. Several studies support the hypothesis of export-led economic growth, that is to say a causality that goes from exports to economic growth. This is the case, for example, of Lee and Huang (2002), Shirazi and Manap (2004), Al Mamun and Nath (2005), Kpemoua (2016), and Bakari and Mabrouki (2017). Contrary to the assumption of export-led economic growth, growth can be a source of increased exports. Causality ranges from economic growth to exports. This assertion is supported by many works 
such as those of Oxley (1993), Mishra (2011), Abbas (2012), Shihab and Abdul-Khaliq (2014), Mehta (2015), Gokmenoglua and Taspinara (2015), and Kalaitzi and Cleeve (2018). However, instead of a single causal relationship, other writers have rather found a circular relationship between exports and economic growth. Thus, when analyzing the relationship between the expansion of exports and economic growth in Côte d'Ivoire, N'Zué (2003) results in a lack of cointegration; but he finds a double causality in the sense of Granger between exports and economic growth. Bhat (1995), Johnson (2006), Elbeydi, Hamuda and Gazda (2010), Hye (2012), Mohsen (2015), and Ajmi, Aye, Balcilar and Gupta (2015) find similar results.

\section{Method}

\subsection{The Approach of Pesaran, Shin and Smith}

In this study we use the estimation and test method of Pesaran et al. (2001) and Pesaran and Shin (1999) to study the relationship between economic growth and exports. This method called Autoregressive Distributed Lag (ARDL) has several advantages over traditional cointegration methods. First, the ARDL approach can be applied with I (1) and/or I (0) variables and that approach make it possible to avoid the classification of the variables into I (1) or I (0). The use of this method therefore does not necessarily require testing the order of integration of the series. Testing the order of series integration may result in an additional degree of uncertainty in the analysis as unit root tests are typically low power (Pesaran, 2015, p526). Secondly, the ARDL approach is more flexible in determining the optimal lag in that the latter may vary from variable to variable; which is not the case in the Johansen $(1988,1991)$ procedure. Third, in the case of small samples, the ARDL method of determining cointegration is relatively more efficient (Acaravci \& Ozturk, 2008). Fourth, the ARDL estimation technique results in unbiased long-run estimators (Harris \& Sollis, 2003). The disadvantage of this test is that it assumes the existence of a single cointegrating relation.

The Pesaran et al. (2001) approach, which assumes a single cointegrating relation, consists in estimating an Error Correction form of an autoregressive model with distributed lags, that is to say

$$
\Delta y_{t}=\alpha+\sum_{i=1}^{p} \phi_{i} \Delta y_{t-i}+\sum_{i=0}^{p} \beta_{i} \Delta x_{t-i}+\delta_{1} y_{t-1}+\delta_{2} x_{t-1}+u_{t}
$$

with $\Delta$ the first difference operator, $\mathrm{u}_{\mathrm{t}}$ the error term and $\mathrm{p}$ the maximum number of lags. The choice of the appropriate number of lags can be made according to the Akaike Information Criterion or Schwarz Bayesian Criterion. Testing the existence of the long-run relationship between the variables $\mathrm{Y}$ and $\mathrm{X}$ is to test the joint hypothesis $\mathrm{H}_{0}: \delta_{1}=\delta_{2}=0$ against the alternative hypothesis $\mathrm{H}_{1}: \delta_{1} \neq 0, \delta_{2} \neq 0$. The critical values of this test are tabulated by Pesaran et al. (2001). The decision rule consists in comparing the Wald statistic denoted W with the upper $\left(\mathrm{W}_{\mathrm{U}}\right)$ and lower $\left(\mathrm{W}_{\mathrm{L}}\right)$ critical values. The upper critical value corresponds to the $\mathrm{I}(1)$ series and the lower critical value refers to the $\mathrm{I}(0)$ variables. Thus, if $\mathrm{W}>\mathrm{W}_{\mathrm{U}}$, we reject the null hypothesis at the indicated significance level and conclude that there is a long-run relationship between the variables under consideration. If $\mathrm{W}<\mathrm{W}_{\mathrm{L}}$, we cannot reject the null hypothesis of no cointegration. Finally, if $\mathrm{W}_{\mathrm{L}}<\mathrm{W}<\mathrm{W}_{\mathrm{U}}$, we are in a zone of indecision.

If we assume that there is only one cointegrating vector, the long-run and short-run equations can be estimated respectively as follows:

$$
\begin{aligned}
y_{t} & =\alpha+\sum_{i=1}^{p} \phi_{i} y_{t-i}+\sum_{i=0}^{p} \beta_{i} x_{t-i}+v_{t} \\
\Delta y_{t} & =\alpha+\sum_{i=1}^{p} \phi_{i} \Delta y_{t-i}+\sum_{i=0}^{p} \beta_{i} \Delta x_{t-i}+\lambda E C M_{t-1}+\varepsilon_{t}
\end{aligned}
$$

where $\lambda$ is the coefficient of the error correction mechanism (ECM).

\subsection{The causality test of Breitung and Schreiber}

The analysis of the causality is made thanks to the test of Breitung and Schreiber (2016) denominated BS. This test is an extension of the Breitung and Candelon (2006) test called BC. Based on the works of Geweke (1982) and Hosoya (1991), Breitung and Candelon construct a frequency band causality test both in the short-run and the long-run. Assuming that the variable $y_{t}$ is caused in the Granger sense by the variable $x_{t}$ under the alternative hypothesis:

$$
y_{t}=a+\sum_{j=1}^{p} \alpha_{j} y_{t-j}+\sum_{k=1}^{p} \beta_{k} x_{t-k}+u_{t}
$$


Breitung and Candelon (2006) show that the null hypothesis of no causality at the frequency $\omega$, or

$M_{x \rightarrow y}(\omega)=0$, is equivalent to the following linear restriction:

$$
H_{0}: R(\omega) \beta=0 \text {, }
$$

with $\beta=\left[\beta_{1}, \ldots, \beta_{p}\right]^{\prime}$ and $R(\omega)=\left[\begin{array}{cccc}\cos (\omega) & \cos (2 \omega) & \ldots & \cos (p \omega) \\ \sin (\omega) & \sin (2 \omega) & \ldots & \sin (p \omega)\end{array}\right], \quad \omega \in(0, \pi)$.

The $F$ statistic of equation (5) roughly follows the distribution $F(2, T-2 p)$ for $\omega \in(0, \pi)$. Breitung and Candelon (2006) recommend using $\mathrm{p} \geq 3$ as the test brings us back to the conventional Granger non-causality test for $\mathrm{p}=1$ or $\mathrm{p}=2$. The $\mathrm{BC}$ test provides better results compared to conventional causality tests (Mermod \& Dudzevičiūte, 2011; Krätschell \& Schmidt, 2012 and Serfraz, 2017). However, as Breitung and Schreiber (2016) have pointed out, the $\mathrm{BC}$ test has a disadvantage in that it is formulated in terms of a single frequency point $\left(\omega_{0}\right)$ that should be specified a priori. Breitung and Schreiber have generalized the null hypothesis of non-causality of the BC test. Instead of testing the null hypothesis of non-causality at frequency $\omega_{0}$ as in the case of the BC test, Breitung and Schreiber test it in a frequency range $\left(\omega_{l}, \omega_{u}\right)$. According to Serfraz (2017) the BS test has three advantages. First, it results in no loss of information. Second, it gives a better overview of the short and long-run relationships. Finally the BS test treats in detail what the BC test ignored because it uses frequency intervals instead of a single frequency point.

\section{Results and Discussion}

\subsection{Data Source}

The data come from the World Bank (2019): World Development Indicators (WDI) database ${ }^{1}$. Lpib and Lexp represent the log of GDP and exports of goods and services respectively. These two variables expressed in current dollars cover the period 1960-2017. Figure 1 shows the evolution of variables in level and in first difference. The observation of this Figure shows series with a trend in level. In first difference, the series become stationary with the elimination of the trend. Graphical analysis is completed with unit root tests.
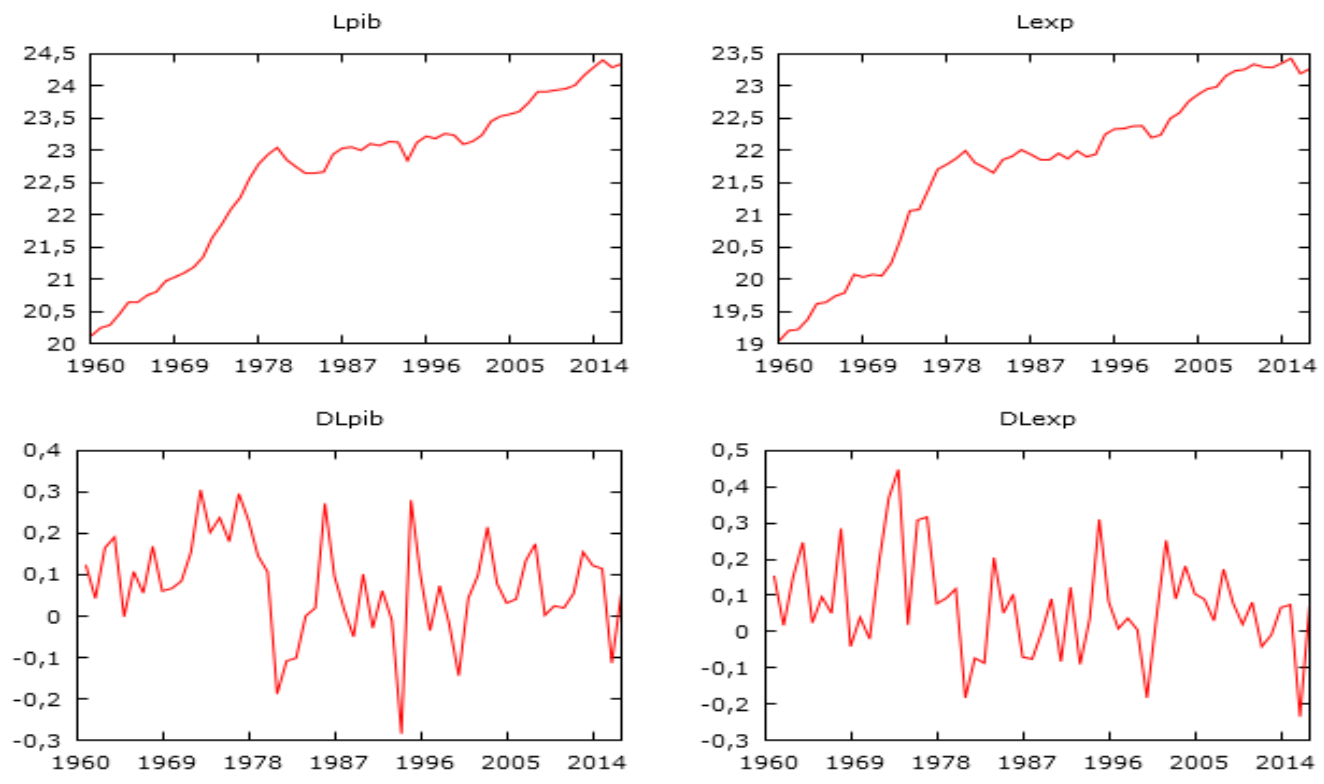

Figure 1. Evolution of variables in level and in first difference

\subsection{Unit Root Tests}

The order of integration of the variables is determined by the ADF and KPSS tests. The maximum lag for the ADF test is set to 10 according to the formula $12(\mathrm{~T} / 100)^{0.25}$, then we chose the optimal lag according to the Schwarz Bayesian criterion. For the KPSS test the truncation is set to 3 according to the formula $4(\mathrm{~T} / 100)^{0.25}$. The null hypothesis is different in the two tests: the ADF test postulates that the series have a unit root whereas

\footnotetext{
${ }^{1}$ We consulted the database on World Bank website in the 7th June 2019.
} 
the KPSS test postulates that the series are stationary. The results presented in Table 1 confirm the conclusions of the graphical analysis. Indeed, the series all have a unit root in level regardless of the test and specification chosen. On the other hand, as a first difference, the two variables become stationary at the $1 \%$ significance level. We can conclude that the variables under study are integrated of order 1, that is to say I (1). Since the two variables are I (1), this requires testing the existence of a possible long term relationship between them, that is to say perform a cointegration test.

Table 1. Unit Root tests results

\begin{tabular}{|c|c|c|c|c|c|}
\hline & $\mathrm{ADF}$ & & & KPSS & \\
\hline Variables & Constant and trend & Constant & None & Constant and trend & constant \\
\hline Lpib & $\begin{array}{l}-1.8976 \\
(0.6557)\end{array}$ & $\begin{array}{l}-2.1834 \\
(0.2144)\end{array}$ & $\begin{array}{l}2.7105 \\
(0.9986)\end{array}$ & 0.2784 & 1.3918 \\
\hline Lexp & $\begin{array}{l}-1.5234 \\
(0.8099)\end{array}$ & $\begin{array}{l}-2.3770 \\
(0.1527)\end{array}$ & $\begin{array}{l}3.9602 \\
(1.000)\end{array}$ & 0.2520 & 1.4077 \\
\hline Dlpib & $\begin{array}{l}-5.6056^{* * * *} \\
(0.0001)\end{array}$ & $\begin{array}{l}-5.4524 * * * \\
(0.0000)\end{array}$ & $\begin{array}{l}-4.3888 * * * \\
(0.0000)\end{array}$ & $0.0877 * * *$ & $0.2765 * * *$ \\
\hline Dlexp & $\begin{array}{l}-6.2830 * * * \\
(0.0000)\end{array}$ & $\begin{array}{l}-6.0216 * * * \\
(0.0000)\end{array}$ & $\begin{array}{l}-5.0111 * * * \\
(0.0000)\end{array}$ & $0.0684 * * *$ & $0.3193 * * *$ \\
\hline
\end{tabular}

Note. The values in parentheses are the p values. $* * *$, means that the variable is stationary at the $1 \%$ significance level. The critical values for the KPSS test are: $0.121(10 \%), 0.149(5 \%)$ and $0.213(1 \%)$ for the model with trend and, $0.351(10 \%), 0.462(5 \%)$ and $0.726(1 \%)$ for the model without trend.

\subsection{Analysis of Cointegration}

Cointegration is performed using the Pesaran et al. (2001) test. The ARDL $(1,1)$ conditional model chosen according to the Schwarz Bayesian criterion for a maximum of 4 lags was estimated with the Microfit 5.0 software. This model validated diagnostic tests that indicate a lack of serial correlation of residuals and heteroscedasticity, a correct functional form and the normality of residuals. The calculated W statistics are reported in Table 2 where each variable is considered dependent variable. When GDP is considered dependent variable the statistic $\mathrm{W}$ is, $\mathrm{W}$ (Lpib $\mid$ Lexp $)=13.0584$. In the case where the exports represent the dependent variable the statistic $\mathrm{W}$ is, $\mathrm{W}(\mathrm{Lexp} \mid \mathrm{Lpib})=4.8636$. From these results, for a $5 \%$ level the null hypothesis of no cointegration is rejected only in the equation where GDP is the dependent variable because the statistic W (Lpib | Lexp) $=13.0584$ is greater than 11.8048 the upper critical value; this validates the use of the Pesaran et al. (2001) cointegration test. This result suggests that there exists a long-run relationship between GDP and exports in Côte d'Ivoire and exports can be treated as "long-run forcing" variable for the explanation of GDP, which implies that there is a long term unidirectional causality that goes from exports to GDP. This result is contrary to that of N'Zué (2003), but it goes in the same direction as that of Al Mamun and Nath (2005).

Table 2. Cointegration test results

\begin{tabular}{lllll}
\hline \multirow{2}{*}{$\begin{array}{l}\text { Dependent } \\
\text { variable }\end{array}$} & W_stat & \multicolumn{2}{c}{ Critical values at 5\% } & Decision \\
\cline { 3 - 4 } & & Lower bound $\left(\mathrm{W}_{\mathrm{L}}\right)$ & Upper bound $\left(\mathrm{W}_{\mathrm{U}}\right)$ & \\
\hline Lpib & 13.0584 & 10.1981 & 11.8048 & Cointegration \\
Lexp & 4.8636 & 10.1981 & 11.8048 & No cointegration \\
\hline
\end{tabular}

Note. Critical values are obtained by simulations after 20000 replications.

\subsection{Estimation of Short Term and Long Term Relationships}

Once the cointegrating relation was established, we estimated short and long-run elasticities, all obtained from the ARDL model $(1,1)$. We tried to take into account the effect of the 2011 political crisis by introducing a dummy variable but this coefficient proved no statistically significant; so we simply removed this dummy variable from the analysis. The results are presented in Tables 3 and 4. The diagnostic tests of the Error Correction Model in Table 4 indicate a good model specification at the $1 \%$ level. The CUSUM (a) and CUSUMSQ (b) tests are shown in Figure 2 in the Appendix. The two statistics are within the corridor defined by the critical values at the 5\% level. This implies that the estimated parameters are stable over the entire period under study.

Both long-run and short-run elasticities are positive and significant at the $1 \%$ level. The long-run elasticity is close to 1 (0.9229), which shows that a $1 \%$ increase in exports causes a $0.92 \%$ increase in GDP. The adjustment 
coefficient has the correct sign (- 0.2915) and is statistically significant at the $1 \%$ level; it reflects a moderate speed of convergence towards the long-run equilibrium.

Table 3. Long-run coefficients

Dependent variable : Lpib

\begin{tabular}{llll}
\hline Variable & Coefficients & t-statistic & Prob \\
\hline Const & $2.7250^{* * *}$ & 4.0950 & 0.000 \\
Lexp & $0.9229 * * *$ & 30.5708 & 0.000 \\
\hline
\end{tabular}

Note. ***, means that the parameter is significant at the $1 \%$ level.

Table 4. Error Correction Model

Dependent variable: Dlpib

\begin{tabular}{llll}
\hline Variable & Coefficients & t-statistic & Prob \\
\hline Const & 0.0000 & 0.00021 & 1.000 \\
DLexp & $0.5613^{* * *}$ & 7.1698 & 0.000 \\
ECM $(-1)$ & $-0.2915^{* * *}$ & -3.6476 & 0.001 \\
$\mathrm{R}^{2}$ & 0.5833 & & 0.000 \\
F_stat $(2 ; 52)$ & 37.7941 & Diagnostic tests \\
\hline \multicolumn{2}{c}{$\mathrm{LM}(1)=1.7405$} \\
\hline Ferial correlation & $\mathrm{LM}(1)=0.1122$ & 0.187 \\
Normality test & $\mathrm{LM}(2)=2.1996$ & 0.738 \\
Heteroskedasticity test & $\mathrm{LM}(1)=0.4302$ & 0.333 \\
\hline
\end{tabular}

Note. $* * *$, means that the parameter is significant at the $1 \%$ level.

\subsection{Analysis of Causality}

The existence of a correlation relationship between the gross domestic product and exports does not clarify the meaning of the causality. Knowledge of the causal relationship is necessary for a correct formulation of economic policy. Indeed, knowing the meaning of causality is as important as highlighting a link between economic variables (Bourbonnais, 2003).

The causality analysis can be done through the usual causality tests, for example the standard Granger non-causality test. The cointegration test presented above showed that there was only one long-run causal relationship ranging from exports to GDP. The Granger causality test (see Table 5) also indicates the presence of a one-way short-run causality that ranges from exports to economic growth. However, as Giles and Williams (1999) note, export-led growth results based on standard causality techniques are not typically robust to specification or method.

Table 5. Short-run Granger Causality Test

\begin{tabular}{llll}
\hline Null hypothesis & Lags & F-Statistics & Conclusion \\
\hline DLPIB does not cause DLEXP & 1 & 0.0118 & Null hypothesis accepted \\
& & $(0.914)$ & \\
DLEXP does not cause DLPIB & 1 & $\left(0.5419^{* *}\right.$ & Rejection of the null hypothesis \\
& &
\end{tabular}

Note. Lags chosen according to the Schwarz Bayesian criterion. Values in parentheses are p-values.

For this reason we focus on the Breitung and Schreiber test (2016). The result of the test is identical if the test is performed in level or in first difference. We used five frequency bands: [0.01, 0.49], [0.52, 0.62], [0.62, 1.3], [1.3, $2.1]$ and $[2.1,3.14]$, a maximum of 3 lags and 50 frequency points within the frequency range. In fact, a short band corresponds to a long period of time and a long band is a short period of time. Therefore, the first band covers approximately a period of 13 years and more, the second band is 10 to 12 years old, the third band is 5 to 10 years old and the last two cover periods of 3 to 5 years and 2 to 3 years respectively. The horizontal axis of the graphs represents the frequencies. The null hypothesis of no causality is rejected each time the line of the test statistic ("teststat") is above the critical value line ("crit.val."). 
First, we present the results of the first version of this test, which is the Breitung and Candelon test (2006). The results presented in Figure 3 indicate a single causal relationship, which ranges from exports to GDP. Indeed, the null hypothesis of absence of causality is rejected for $\omega \epsilon[0.01,0.49]$ which corresponds to a cycle with a length of 13 periods (years) and more. The results of the Breitung and Schreiber (2016) test in Figure 4 confirm the results of the cointegration test and those of the Breitung and Candelon test but invalidate the results of the standard Granger causality test. In fact, the null hypothesis of no causality could not be rejected in the frequency bands [0.52, 0.62], [0.62, 1.3], [1.3, 2.1] and [2.1, 3.14] which represent medium-term and short-term periods. A single causal relationship ranging from exports to GDP in the frequency band [0.01, 0.49], which represents a long period of time, is observed. Overall, the results show that it is exports that drive economic growth and not the opposite in Côte d'Ivoire. The export-led growth hypothesis is verified in Côte d'Ivoire in the long term. In sum, we can say that exports are an important and significant determinant of Ivorian economic growth. The policy of trade openness adopted by the country and the export promotion actions carried out by structures such as APEX-CI since its creation in 1960, can justify this result. The country would certainly gain more by improving the degree of processing of products.

i) H0 : Lexp does not cause Lpib

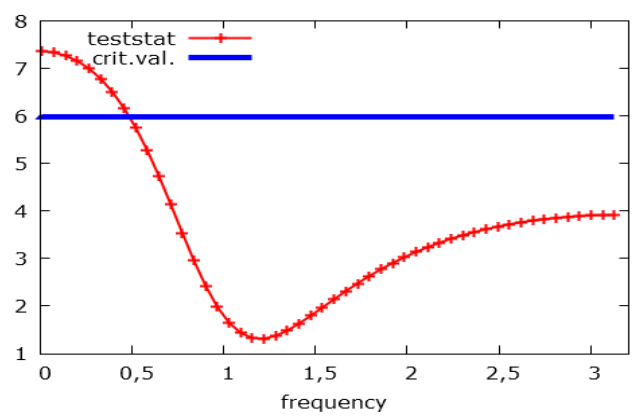

ii) H0 : Lpib does not cause Lexp

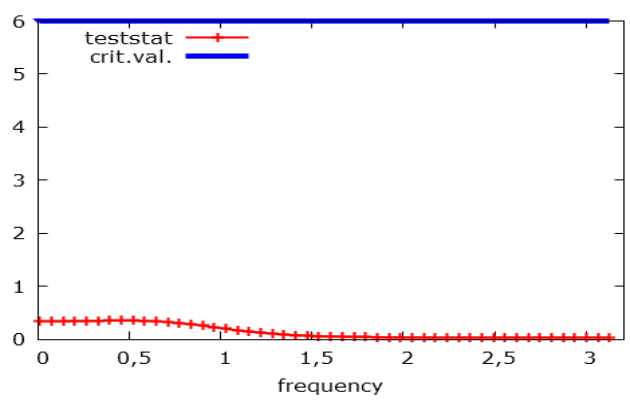

Figure 3. Breitung-Candelon causality test results ${ }^{2}$

* Frequency band : [0.01, 0.49]

i) H0 : Lexp does not cause Lpib

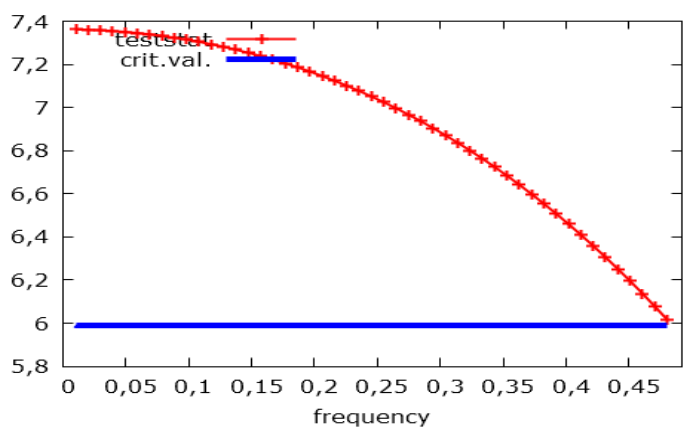

Frequency band : $[0.52,0.62]$

i) H0 : Lexp does not cause Lpib

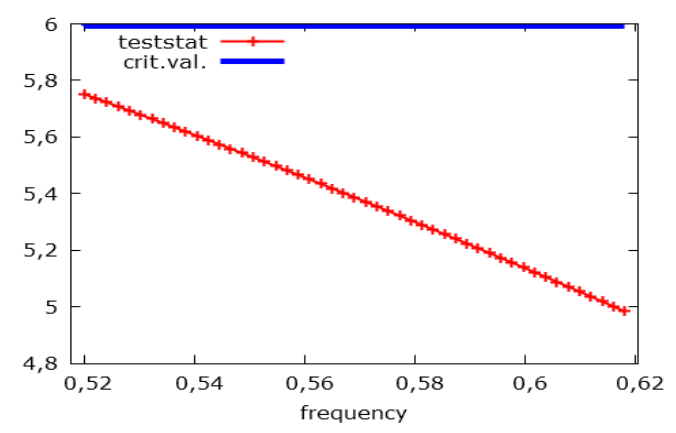

ii) H0 : Lpib does not cause Lexp

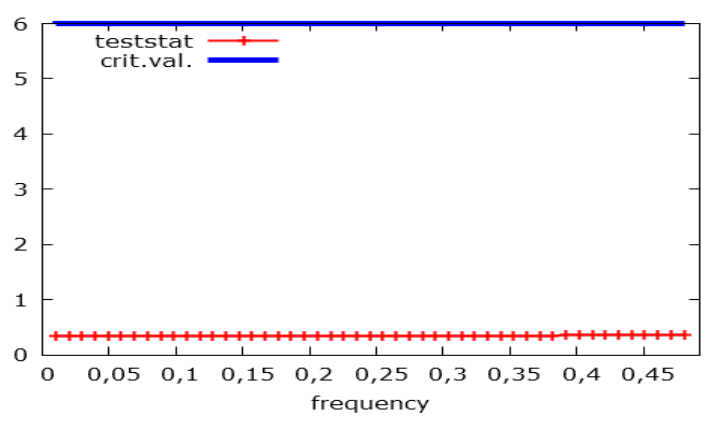

ii) H0 : Lpib does not cause Lexp

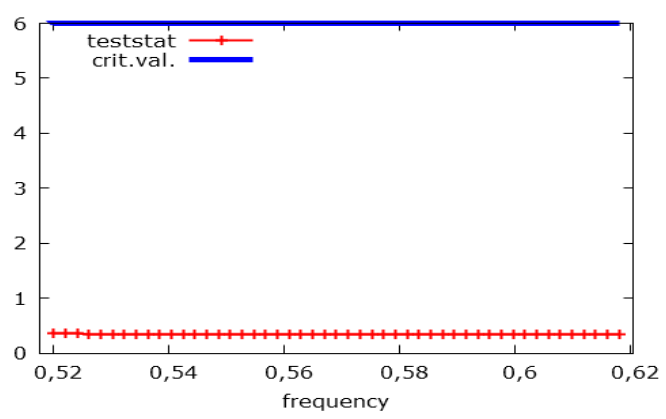

${ }^{2}$ Breitung and Candelon (2006) test and that of Breitung and Schreiber (2016) were implemented by using the Gretl package "BreitungCandelonTest 2.5" written by Schreiber (2018). 
* Frequency band : $[0.62,1.3]$

i) H0 : Lexp does not cause Lpib

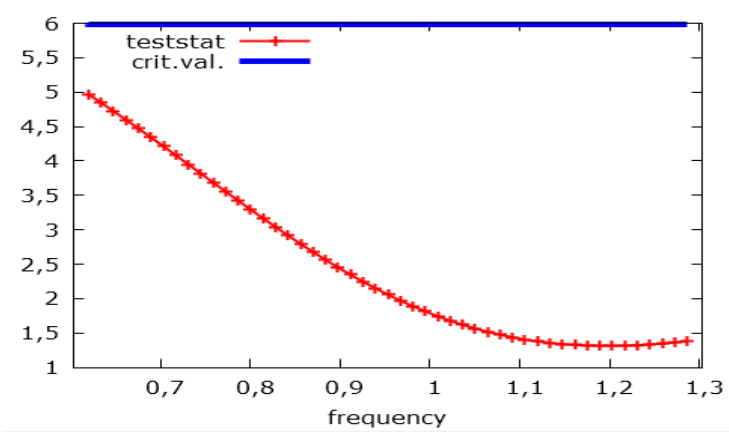

Frequency band : $[1.3,2.1]$

i) H0 : Lexp does not cause Lpib

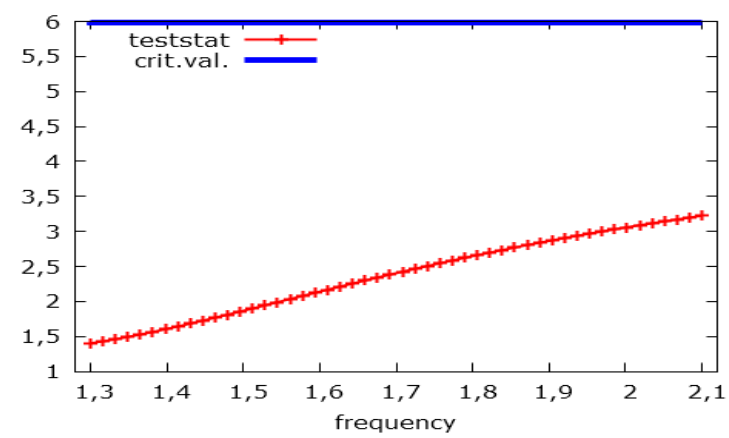

Frequency band : [2.1,3.14]

i) H0 : Lexp does not cause Lpib

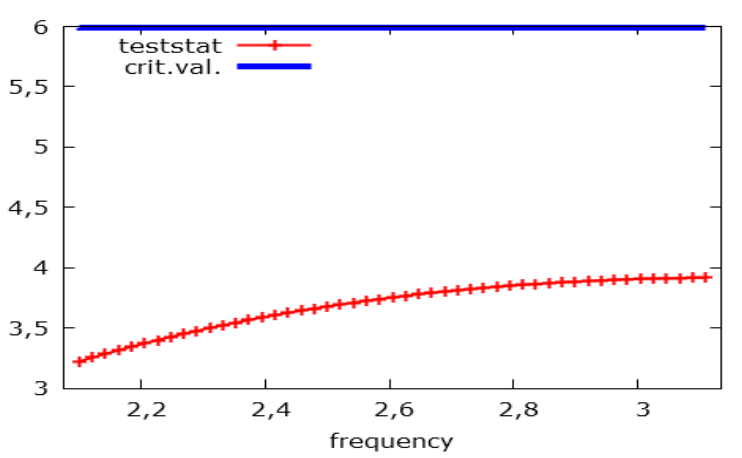

ii) H0 : Lpib does not cause Lexp

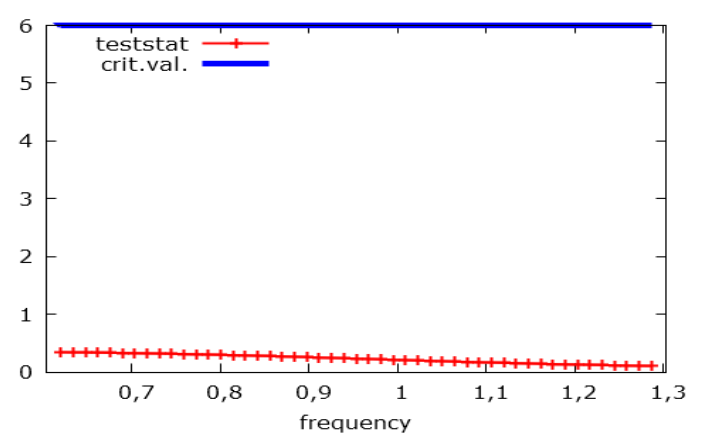

ii) H0 : Lpib does not cause Lexp

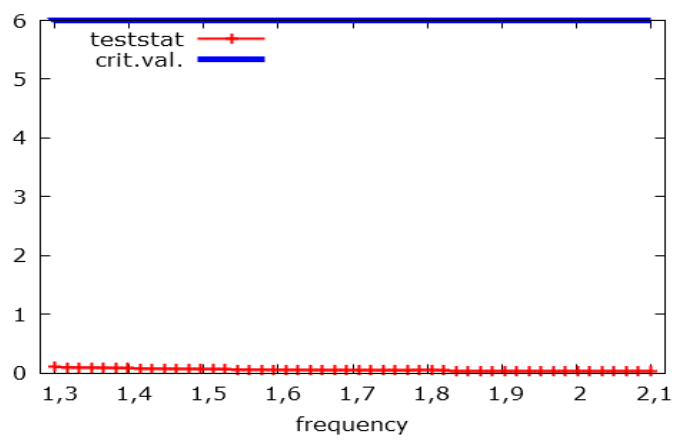

ii) H0 : Lpib does not cause Lexp

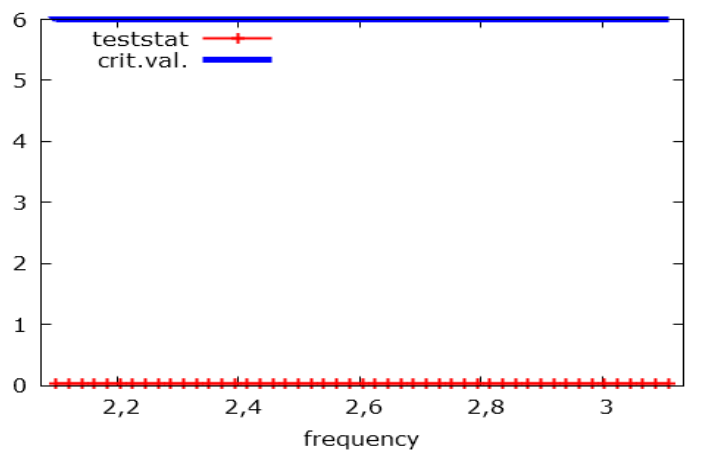

Figure 4. Breitung-Schreiber causality test results

\section{Conclusion}

In this paper we examined the relationship between exports and economic growth in Côte d'Ivoire from 1960 to 2017. The results indicated the existence of a cointegrating relation between economic growth and exports. The analysis of cointegration showed that there was only one long-run causal relationship ranging from exports to GDP. The estimation of an ARDL model $(1,1)$ reveals that exports act positively and significantly on economic growth in the short-run as well as in the long-run. The frequency band causality test of Breitung and Schreiber (2016) confirmed the existence of a long-run unidirectional causal relationship ranging from exports to GDP. It is therefore exports that drive economic growth in Côte d'Ivoire and not the opposite. The results suggest that exports are a major determinant of Ivorian economic growth. To enhance the impact of exports on economic growth, the country should increase the share of manufactured goods in exports and strengthen export promotion policies. 


\section{Acknowledgements}

We would like to thank anonymous referees for useful suggestions to the improvement of the quality of this paper. We are also grateful to Sven Schreiber for making public the estimate code of the causality tests of Breitung and Candelon (2006) including that of Breitung and Schreiber (2016). The authors are responsible for any remaining errors.

\section{References}

Abbas, S. (2012). Causality between exports and economic growth: Investigating suitable trade policy for Pakistan. Eurasian Journal of Business and Economics, 5(10), 91-98.

Acaravci, A., \& Ozturk, I. (2008). Twin deficits phenomenon : Empirical evidence from the ARDL bound test approach for Turkey. Bulletin of Statistics \& Economics, 2, 56-64.

Ajmi, N. A., Aye, C. G., Balcilar, M., \& Gupta, R. (2015). Causality between exports and economic growth in South Africa : Evidence from linear and nonlinear tests. The Journal of Developing Areas, 49(2), 163-181. https://doi.org/10.1353/jda.2015.0021

Al Mamun, A. K., \& Nath, K. H. (2005). Export-led growth in Bangladesh: A time series analysis. Applied Economics Letters, 12, 361-364. https://doi.org/10.1080/13504850500068194

Bakari, S., \& Mabrouki, M. (2017). Impact of exports and imports on economic growth : New evidence from Panama. Journal of Smart Economic Growth, 2(1), 67-79.

Balassa, B. (1985). Exports policy choice and economic growth in developing countries after the 1973 oil shock. Journal of Development Economics, 18(1), 22-35. https://doi.org/10.1016/0304-3878(85)90004-5

Bhat, K. S. (1995). Export and economic growth in India. Artha Vijana, 37(4), 350-358. https://doi.org/10.21648/arthavij/1995/v37/i4/115968

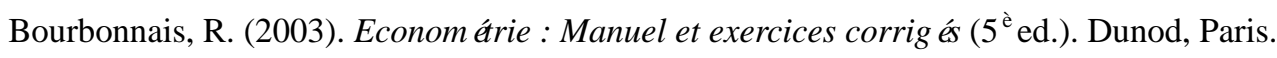

Breitung, J., \& Candelon, B. (2006). Testing for short and long-run causality: A frequency-domain approach. Journal of Econometrics, 132, 363-378. https://doi.org/10.1016/j.jeconom.2005.02.004

Breitung, J., \& Schreiber, S. (2016). Assessing causality and delay within a frequency band. IMK Working Paper No. 165. Retrieved from http://www.boeckler.de/imk_5279.htm?produkt=HBS-006295

Colombatto, E. (1990). An analysis of exports and growth in LDCs. Kyklos, 43(4), 579-597. https://doi.org/10.1111/j.1467-6435.1990.tb02238.x

Ee, Y. C. (2016). Export-led growth hypothesis: Empirical evidence from selected Sub-saharan African countries. Procedia Economics and Finance, 35, 232-240. https://doi.org/10.1016/S2212-5671(16)00029-0

Elbeydi, K. R. M., Hamuda, A. M., \& Gazda, V. (2010). The relationship between export and economic growth in Libya Arab Jamahiriya. Theoretical and Applied Economics, 1(542), 69-76.

Fatemah, A., \& Qayyum, A. (2018). Modeling the impact of exports on the economic growth of Pakistan. MPRA paper No. 83929. Retrieved from https://mpra.ub.uni-muenchen.de/83929/

Geweke, J. (1982). Measurement of linear dependence and feedback between multiple time series. Journal of the American Statistical Association, 77, 304-313. https://doi.org/10.1080/01621459.1982.10477803

Giles, A. J., \& Williams, L. C. (1999). Export-led growth: A survey of the empirical literature and some noncausality results. Econometrics Working Paper EWP9901. https://doi.org/10.2139/ssrn.146208

Gokmenoglua, K. K., \& Taspinara, N. S. Z. (2015). The export-led growth: A case study of Costa Rica. Procedia Economics and Finance, 25, 471-477. https://doi.org/10.1016/S2212-5671(15)00759-5

Harris, R., \& Sollis, R. (2003). Applied time series modelling and forecasting. Wiley, Wes Sussex.

Heller, P. S., \& Porter, R. C. (1978). Exports and growth : An empirical reinvestigation. Journal of Development Economics, 5, 191-193. https://doi.org/10.1016/0304-3878(78)90007-X

Hosoya, Y. (1991). The decomposition and measurement of the interdependency between second-order stationary processes. Probability Theory and Related Fields, 88, 429-444. https://doi.org/10.1007/BF01192551

Hye, Q. M. (2012). Exports, imports and economic growth in China: An ARDL analysis. Journal of Chinese Economic and Foreign Trade Studies, 4(1), 42-55. https://doi.org/10.1108/17544401211197959 
Johansen, S. (1988). Statistical analysis of cointegration vectors. Journal of Economic Dynamics and Control, 12, 231-254. https://doi.org/10.1016/0165-1889(88)90041-3

Johansen, S. (1991). Estimation and hypothesis testing of cointegration vectors in Gaussian vector autoregressive models. Econometrica, 59, 1551-1580. https://doi.org/10.2307/2938278

Johnson, D. (2006). Exportations et croissance économique : Une analyse empirique sur le Togo. Revue du CAMES, 007(2), 267-278.

Kalaitzi, S. A., \& Cleeve, E. (2018). Export-led growth in the UAE : Multivariate causality between primary exports, manufactured exports and economic growth. Eurasian Business Review, 8(3), 341-365. https://doi.org/10.1007/s40821-017-0089-1

Kpemoua, P. (2016). Exportations et croissance économique au Togo. Extrait de https://halshs.archives-ouvertes.fr/halshs-01332738

Krätschell, K., \& Schmidt, T. (2012). Long-run trends or short-run fluctuations - What establishes the correlation between oil and food prices? Ruhr Economic Papers \#357. https://doi.org/10.2139/ssrn.2123084

Lee, C. H., \& Huang, B. N. (2002). The relationship between exports and economic growth in East Asian countries: A multivariate threshold autoregressive approach. Journal of Economic Development, 27(2), 45-68.

Mehta, N. S. (2015). The dynamics of relationship between exports, import and economic growth in India. International Journal of Research in Humanities \& Soc. Sciences, 3(7), 39-47.

Mermod, A. Y., \& Dudzevičiūtè, G. (2011). Frequency domain analysis of consumer confidence, industrial production and retail sales for selected European countries. Journal of Business Economics and Management, 4, 589-602. https://doi.org/10.3846/16111699.2011.599406

Michaely, M. (1977). Export and growth: An empirical investigation. Journal of Development Economics, 4, 49-54. https://doi.org/10.1016/0304-3878(77)90006-2

Mishra, K. P. (2011). The dynamics of relationship between exports and economic growth in India. International Journal of Economic Sciences and Applied Research, 4(2), 53-70.

Mohsen, S. A. (2015). Effects of oil and non-oil exports on the economic growth of Syria. Academic Journal of Economic Studies, 1(2), 69-78.

N'zué, F. F. (2003). Le rôle des exportations dans le processus de croissance économique de la Côte d'Ivoire: Ses implications pour des stratégies de création d'emplois durables. African Development Bank, 199-217. https://doi.org/10.1111/j.1467-8268.2003.00071.x

Oxley, L. (1993). Cointegration, causality and export-led growth in Portugal, 1865-1985. Economics Letters, 43(2), 163-166. https://doi.org/10.1016/0165-1765(93)90030-G

Pesaran, M. H. (2015). Time series and panel data econometrics. Oxford University Press. https://doi.org/10.1093/acprof:oso/9780198736912.001.0001

Pesaran, M. H., \& Shin, Y. (1999). An autoregressive distributed lag modelling approach to cointegration analysis. In S. Strom \& P. Diamond (Eds.), Econometrics and Economic Theory in the 20th Century: The Ragnar Frisch Centennial Symposium. Cambridge : Cambridge University Press.

Pesaran, M. H., Shin, Y., \& Smih, R. J. (2001). Bounds testing approaches to the analysis of level relationships. Journal of Applied Econometrics, 16, 289-326. https://doi.org/10.1002/jae.616

Saminirina, A., \& Adamson, R. (2013). Exportations, croissance économique et intégration régionale : La relation entre exportations et croissance économique à Madagascar. Centre de Recherches, d'Etudes et d'Appui à l'Analyse Economique à Madagascar (CREAM), Cahier nº 16.

Schreiber, S. (2018). BreitungCandelonTest, version 2.5. Retrieved from http://ricardo.ecn.wfn.edu/gretl/cgi-bin/current_fnfiles/BreitungCandelonTest.gfn

Serfraz, A. (2017). Analyzing short-run and long-run causality between FDI flows, labour productivity and education in Pakistan, Discussion Papers No. 61. Retrieved from http://hdl.handle.net/10419/162068

Shihab, A. R., \& Abdul-Khaliq, S. S. (2014). The causal relationship between exports and economic growth in Jordan. International Journal of Business and Social Science, 5(3), 302-308.

Shirazi, S. N., \& Manap, A. A. T. (2004). Exports and economic growth nexus: The case of Pakistan. The 
Pakistan Development Review, 43(4), 563-581. https://doi.org/10.30541/v43i4IIpp.563-581

Subasat, T. (2002). Does export promotion increase economic growth? Some cross-section evidence. Development Policy Review, 20(3), 333-349. https://doi.org/10.1111/1467-7679.00175

Tyler, W. G. (1981). Growth and export expansion in developing countries: Some empirical evidence. Journal of Development Economics, 9, 121-130. https://doi.org/10.1016/0304-3878(81)90007-9

Vohra, R. (2001). Export and economic growth: Further time series evidence from less developed countries. International Advances in Economic Research, 7(3), 345-350. https://doi.org/10.1007/BF02295403

Wei, S. J. (1993). Open door policy and China's rapid growth: Evidence from city level data. NBER Working Paper No. 4602. https://doi.org/10.3386/w4602

World Bank. (2019). World Development Indicators database. Retrieved from http://databank.worldbank.org/data/download/WDI_excel.zip

\section{Appendix}

a)

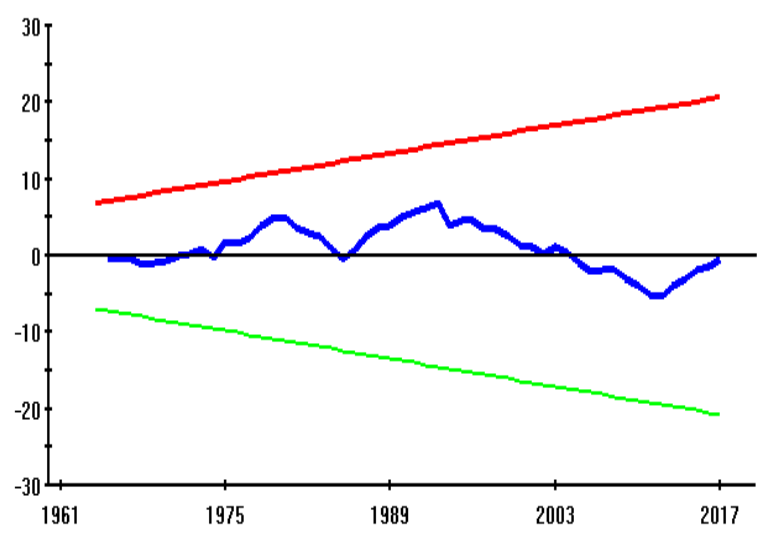

b)

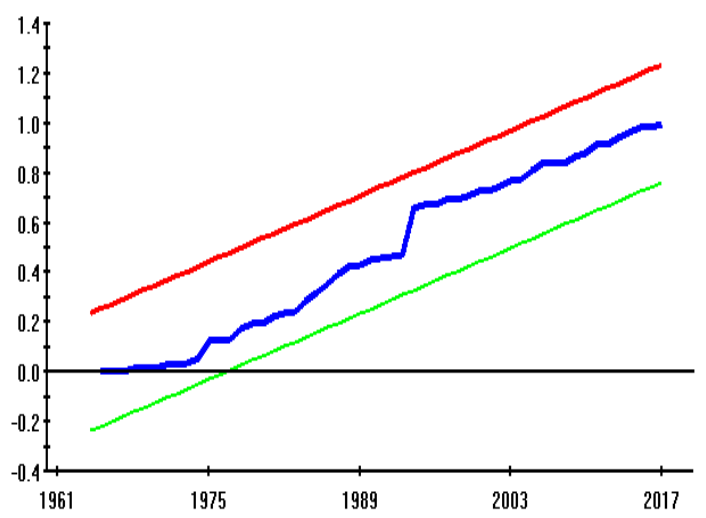

Figure 2. CUSUM and CUSUMSQ tests

\section{Copyrights}

Copyright for this article is retained by the author(s), with first publication rights granted to the journal.

This is an open-access article distributed under the terms and conditions of the Creative Commons Attribution license (http://creativecommons.org/licenses/by/4.0/). 